\title{
LINKING LAND COVER CHANGES IN THE SUB-ALPINE AND MONTANE BELTS TO CHANGES IN A TORRENTIAL RIVER
}

\author{
Yasmina Sanjuán, Amelia Gómez-Villat, Estela Nadal-Romero , Javier Alvarez-Martínez, José Amáez . \\ Marra P. Serrano-Muela , Juan Manuel Rubialé , Penelope Gonzalez-Sampérix , Jose M. García-Ruiz
}

\begin{abstract}
Channel changes are the consequence of changes in sediment yield from the slopes and in the connectivity between slopes and channels because of distinct land use and climate impacts. In this study, we investigated the characteristics and evolution of a short reach in the headwater of the Ijuez River, central-southem Pyrenees. Assessment of a series of sedimentary and geomorphic structures confirmad major changes to the valley bottom, mainly related to changes in the intensity of hurnan activity. The oldest sedimentary siructure is a terrace level located 3 to $4 \mathrm{~m}$ ahove the curnent alluvial plain. General deforestation, overgrazing and recurring fires in the montane belt (1 100-1600 ma.s.1) have led to increased soil erosion and connectivity, and to the triggering of debris flows that have been deposited on the fluvial terace. Woody fragments from within the debris tows were dated using accelerator mass spectrometry " between 100 and $115 \mathrm{cal}$ years $\mathrm{BP}_{\text {, }}$ which coincides with the periad of maximum deforestation and human density in the Pyrenees. Depopulation and farmland atandonment since the beginning of the 20 ch century has resulced in generalizsd natural and antificial reforestation, a shrinkage of the eroded areas and a decline in connectivity between slopes and the channel. The most important consequence has been channel incision and narrowing, and the development of a sediment armour layer. Active sediment transport is continuing, although there bas been a decrease in sodiment yield from the slopes. Copynght 9014 John Wiley \& Sons, Ltd.
\end{abstract}

